\title{
APLIKASI PEMBELAJARAN BERBASIS AUGMENTED REALITY PADA BUKU PENGENALAN ALAT MUSIK MODERN UNTUK ANAK
}

\author{
Mohamad Sofiudin ${ }^{1}$, Tubagus Mohammad AKhriza², Dinny Wahyu Widarti (Corresponding author) ${ }^{3}$ \\ ${ }^{1)}$ Sistem Informasi, STMIK Pradnya Paramita \\ Jl. LA Sucipto 249A Blimbing Malang \\ Telp 0341-412699 \\ ez.zhofie@gmail.com, akhriza@stimata.ac.id, dinnywidarti@gmail.com
}

\begin{abstract}
The use of augmented reality (AR) technology as a learning medium for modern musical instruments aims to overcome the limitations of schools in terms of the procurement of musical instruments, as well as to increase the value of student understanding and provide a more interactive experience. Modern AR-based learning instruments application featuring $3 D$ objects and $3 D$ videos of modern musical instruments. The application is built for mobile devices operating on Android. Based on the results of testing the device, the application can run perfectly on devices with a RAM specification of $0.5 \mathrm{~GB}$ and above. Tests were also conducted on Diponegoro Islamic elementary school students and teachers, these students experienced an increase in understanding of modern musical instruments, while testing of teachers to measure the interactivity of applications.
\end{abstract}

\section{Keywords : Learning media, augmented reality, modern musical instruments, android}

\section{PENDAHULUAN}

Pengenalan seni musik seperti alat musik modern sejak dini dianggap perlu karena masa ini merupakan masa perkembangan kecerdasan yang pesat. Fasli dan Jalai (2012) menjelaskan bahwa hingga usia anak delapan tahun, kecerdasannya dapat meningkat dari $30 \%$ menjadi $80 \%$. Masa usia dini juga lebih sensitif dan progresif dalam mengembangkan kemampuan verba, terutama untuk mengenalkan alat musik modern.

Pembelajaran seni musik di sekolah biasanya dilakukan oleh guru dengan memberikan contoh atau menghadirkan alat peraga. Namun pada kenyataannya, seringkali banyak ditemukan guru yang kurang mampu memainkan alat musik atau kadang karena terkendala pada mahalnya alat musik tersebut yang menyebabkan instansi sekolah tidak cukup mampu untuk membelinya. Seperti dilansir dari situs jualalatmusik.com, misal satu set alat musik yang terdiri dari beberapa alat musik sekaligus, seperti : gitar, bass, drum dan juga keyboard harga berada dikisaran 35.000.000,sampai 68.000.000,- Rupiah. Memahami harga yang cukup mahal, wajar jika sekolah merasa berat untuk membelinya, terutama sekolah setingkat Sekolah Dasar (SD) dan Taman Kanak-Kanak (TK). Masalah tersebut secara tidak langsung berakibat pada menurunnya pemahaman anak didik pada seni dan alat musik. Ketidakmampuan untuk memiliki dan mempraktekkan alat musik tersebut di rumah secara intensif tentunya dapat berdampak pada menurunnya semangat belajar anak didik.

Adapun solusi lain yang ditawarkan guru yaitu dengan media tekstual seperti pemanfaatan buku, namun teori-teori didalamnya bagi anak usia dini cenderung dianggap kurang dapat dipahami sehingga para siswa malas untuk membacanya.
Media pembelajaran selanjutnya yang biasa digunakan adalah pemanfaatan video dimana kenyataan yang terjadi dilapangan adalah bahwa media pembelajaran tersebut kurang interaktif dalam meneyediakan komunikasi aktif dua arah dengan para siswa.

Salah satu media yang dapat digunakan sebagai solusi dari permasalahan-permasalahan tersebut di atas adalah dengan memanfaatkan teknologi Augmented reality (AR). AR merupakan sebuah teknologi dalam dunia komputer yang menggabungkan antara dunia nyata dan dunia virtual. Dengan mengarahkan kamera AR ke marker (suatu penanda untuk memunculkan objek), maka objek virtual akan tampil di atas dunia nyata dalam bentuk objek virtual dua atau tiga dimensi (2D atau 3D). Sifatnya yang mengandung obyek virtual 3D meningkatkan sisi realitas dari objek dan membuatnya berguna sebagai alat untuk membantu meningkatkan persepsi dan interaksi penggunanya dengan dunia nyata. Informasi yang ditampilkan oleh benda virtual dapat membantu penggunanya melaksanakan kegiatan-kegiatan dalam dunia nyata. Tidak seperti realitas maya yang sepenuhnya menggantikan kenyataan, namun AR hanya menambahkan atau melengkapi kenyataan (Azuma, et.al., 2001).

Di dalam media pembelajaran berbasis AR ini siswa dan guru akan mendapatkan solusi untuk mengatasi kekurangan-kekurangan media pembelajaran tekstual dan video yang tradisional, diantaranya adalah siswa dapat melihat bentuk alat musik, mendengarkan bunyi yang dihasilkan dari setiap alat musik, membaca sejarah dari mana masing-masing alat musik berasal dan video tentang bagaimana cara menggunakan setiap alat musik tersebut secara virtual langsung menggunakan 
Android dengan fokus penyajian data dan input lebih interaktif dengan penggunanya. Pemanfaatan Android dipilih karena saat ini setiap kalangan baik dari usia anak-anak hingga dewasa pada umumnya memiliki android. Pun Android lebih praktis sehingga dapat digunakan oleh siapapun baik guru maupun anak didik, serta dapat digunakan dimanapun sehingga anak didik dapat memanfaatkannya diluar jam sekolah. Dari permasalahan tersebut, maka penelitian ini mengambil judul "APLIKASI PEMBELAJARAN BERBASIS AUGMENTED REALITY PADA BUKU PENGENALAN ALAT MUSIK MODERN UNTUK ANAK".

Mustika, Ceppi Gustiar Rampengan, Rheno Sanjaya dan Sofyan (2015) melakukan penelitian mengenai implementasi Augmented reality untuk mengukur baju wisudawan/i Universitas Dian Nuswantoro.

Meylisa Rasjid, Rizal Sengkey, Stanley Karouw (2016) melakukan penelitian mengenai implementasi Augmented Reality alat musik Kolintang yang dapat berjalan pada sistem operasi android.

Daniel Hero Fersil Punuindoong, H Meidia (2017) melakukan penelitian pengembangan sebuah aplikasi untuk media pembelajaran bentuk chord dan melodi pada alat musik gitar secara mobile berbasisAugmented Reality menggunakan metode markerbased system dengan Vuforia SDK sebagai library AR.

Noviana, Akhriza dan Farida (2017) mengusulkan penggunaan AR untuk meningkatkan pemahaman pembelajaran mengenai rambu-rambu lalu lintas bagi anak-anak.

Tommi Suryant, Ema Utami, Hanif Al Fatta (2014) melakukan analisis faktor-faktor yang berpengaruh dalam pendeteksian interaksi dan bagaimana interaski dapat dideteksi oleh sistem dan dengan adanya aplikasi "augmented reality gamelan" anak muda yang memiliki media smartphone dapat memainkan aplikasi virtual gamelan ini dimana saja dengan media marker yang dapat langsung berinteraksi seolah-olah bermain gamelan.

Risyan Arief Setyawan, Afdhol Dzikri (2016) dalamJurnalnya "Analisis Penggunaan Metode Marker Tracking Pada Augmented reality Alat Musik Tradisional Jawa Tengah". Tujuan penelitian ini adalah modifikasi dari single marker menjadi markerless sehingga mampu melakukan scanning tanpa membuat marker atau penanda objek 2D.

Berdasarkan berbagai penelitian yang membahas augmented reality dapat ditarik kesimpulan bahwa penggunaan augmented reality sebagai media pembelajaran saat ini banyak diminati baik oleh pengguna maupun developer. Augmented reality diterapkan sebagai suatu media pembelajaran yang inovatif dengan proses pembelajaran menampilkan objek secara 3 dimensi. Dengan adanya augmeneted reality pengguna dapat dengan mudah menvisualisasikan bentuk alat musik modern secara 3 dimensi serta dapat mengetahui masingmasing fungsi alat musik tersebut dengan lebih detail dan nyata. Penggunaan aplikasi ini dirasa bisa bermanfaat diterapkan dalam proses pembelajaran di sekolah, yang cukup mempermudah guru dalam mempresentasikan materi kesenian musik.

\section{METODE}

Metode yang digunakan dalam penelitian ini adalah Marker Based Trackingdimana AR menggunakan marker atau penanda objek dua dimensi yang memiliki suatu pola yang akan dibaca Android melalui media kamera. Adapun Cara kerja augmented reality dalam menambahkan objek virtual ke lingkungan nyata dapat dilihat pada Gambar 1 (Villagomez, G. 2010).

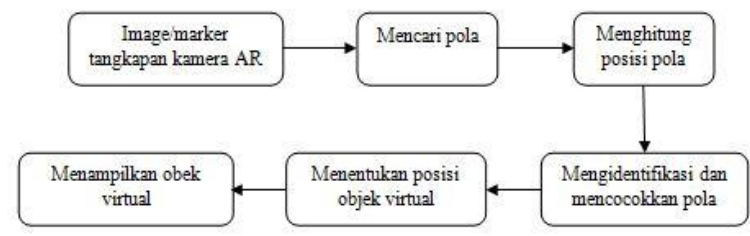

Gambar 1. Cara kerja augmented reality

a. Perangkat kamera input menangkap video dan mengirimkan ke processor.

b. Perangkat lunak dalam processor mencari suatu pola

c. Perangkat lunak menghitung posisi pola untuk mengetahui posisi objek virtual yang akan diletakkan

d. Perangkat lunak mengidentifikasi pola dan mencocokkan dengan informasi yang dimiliki perangkat lunak.

e. Objek virtual akan ditambahkan sesuai dengan hasil pencocokan informasi dan diletakkan pada posisi yang telah dihitung sebelumnya.

f. Objek virtual akan ditampilkan melalui perangkat tampilan.

Pengujian selanjutnya adalah untuk mengukur keefektifan aplikasi dalam memberikan pemahaman kepada user. Dengan menggunakan kuesioner, pengujian dilakukan pada responden dengan menggunakan metode skala likert. Rentang skala yang digunakan dalam pengujian adalah 1 sampai 5 dengan bentuk jawaban antara lain: sangat setuju, setuju, ragu-ragu, tidak setuju, dan tidak setuju.

Berikut adalah prosedur yang dilakukan dalam pengujian ini :

a. Peneliti mengumpulkan item-item pertanyaan yang memiliki relevansi dengan masalah yang sedang diteliti, dan terdiri dari perihal yang 
disukai dan tidak disukai.

b. Sealanjutnya kuesioner dicoba pada responden, yaitu siswa dan guru SD Islam Diponegoro.

c. Responden di atas diminta untuk mengecek tiap item dan memberikan penilaian pada seteiap item dengan skala 1 sampai 5.

d. Respon dianalisis dan disajikan peneliti dalam bentuk rangkuman persentase dan grafik.

\section{PEMBAHASAN}

\subsection{Tampilan Halaman Splashscreen}

Halaman Splashscreen ditampilkan sebagai pembuka sebelum masuk halamanmain menu. Halaman splashscreen ditampilkan untuk mengenalkan aplikasi pada pengguna. Halaman Splashscreen aplikasi ditunjukkan pada Gambar 2.

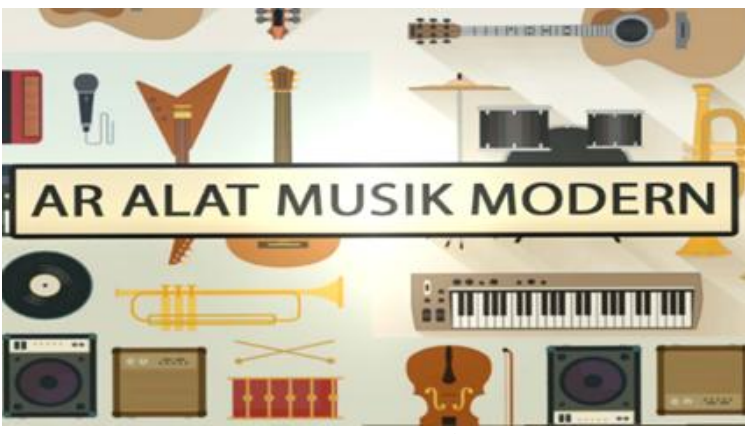

Gambar 2. Halaman Splashcreen

\subsection{Tampilan Halaman Main Menu}

Halaman main menu ditampilkan setelah halaman splashscreen (Gambar 2). Halaman main menu menampilkan beberapa tombol menu aplikasi. Halaman main menu pada aplikasi ditunjukkan pada Gambar 3 .

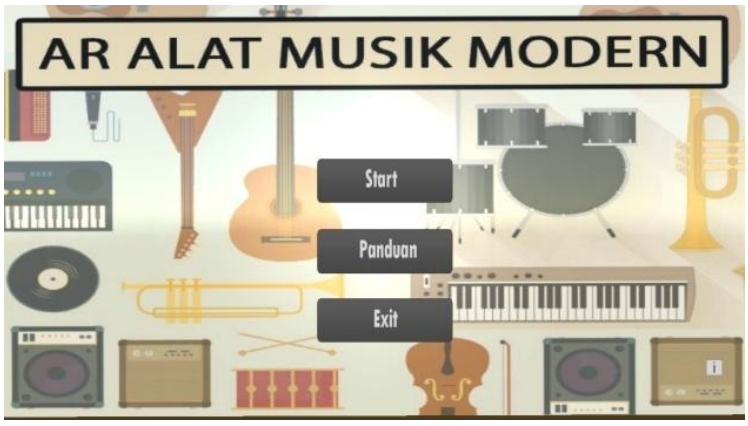

Gambar 3. Halaman Main Menu

Berikut adalah penjelasan dari Gambar 3.

a. Start berfugsi untuk memulai aplikasi AR alat musik modern.

b. Panduan berfungsi untuk menampilkan halaman pop up GUI panduan instal aplikasi dan penggunaan aplikasi.

c. Exit digunakan untuk menutup aplikasi.

\subsection{Tampilan Halaman AR Alat Musik Modern}

Halaman AR alat musik modern akan tampil ketika tombol start pada main menu ditekan. Halaman AR alat musik modern akan menjalankan kamera AR yang jika diarahkan pada marker objek alat music akan menampilkan objek 3D alat musik modern diantaranya gitar, piano, keyboard, saksofon, terompet, drum dan biola. Gambaran lebih jelasnya untuk contoh gambar alat music tersebut dapat ditunjukkan pada Gambar 4 sebagai contoh gambar alat musik gitar, dan Gambar 5 sebagai contoh alat musik terompet.

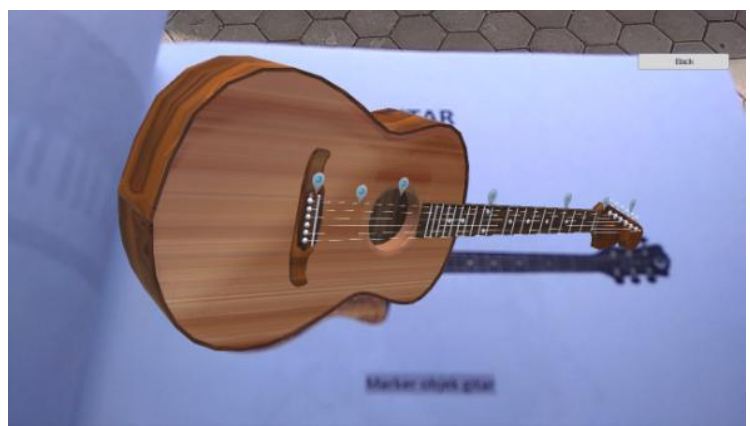

Gambar 4. Objek 3D Alat Musik Modern pada Halaman Kamera AR (Contoh Objek Gitar)

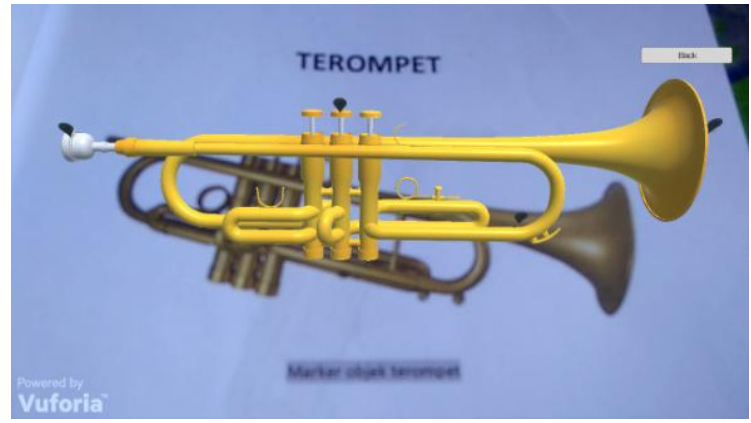

Gambar 5. Objek 3D Alat Musik Modern pada Halaman Kamera AR (Contoh Objek Terompet)

Pada Gambar 4 dan 5 terdapat point marker yang jika ditekan akan menampilkan pop up GUI yang menampilkan informasi fungsi pada setiap bagian alat musik. Selain itu objek juga mendukung interaksi antara pengguna dan aplikasi yang interaktif yaitu dengan dukungan kustomisasi rotasi menggunakan sentuhan tangan (touch). Pengguna dapat melakukan fungsi rotasi dalam berbagai sudut kemiringan (tidak terbatas).

Selanjutnya jika kamera AR diarahkan pada marker video maka akan ditampilkan objek 3D video cara penggunaan setiap alat music seperti ditunjukkan pada Gambar6. 


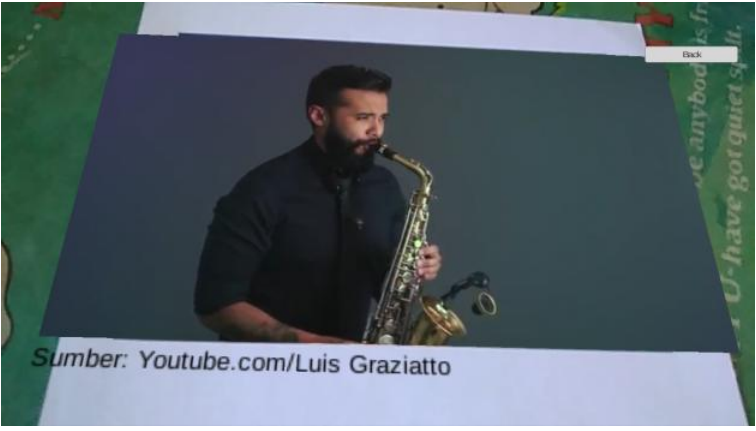

Gambar 6. Video Prewedding pada Halaman AR Alat Musik Modern

\subsection{Tampilan Halaman Panduan}

Halaman Panduan akan tampil ketika tombol panduan pada menu utama ditekan. Halaman panduan berfungsi untuk membantu pengguna dalam instal aplikasi dan penggunaan aplikasi. Halaman panduan ditunjukkan pada Gambar 7.

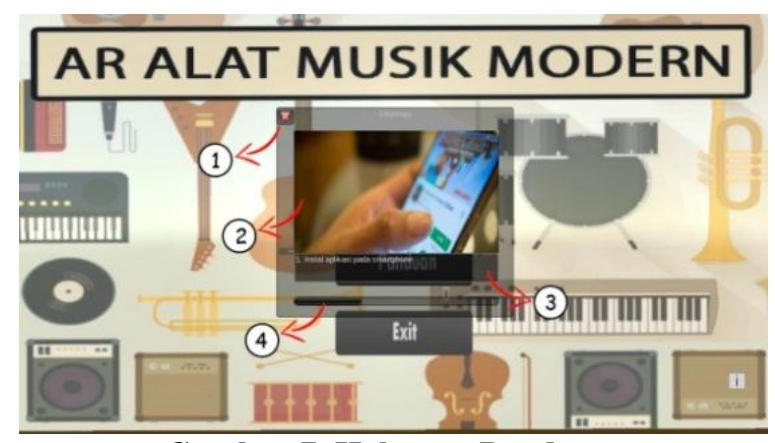

Gambar 7. Halaman Panduan

Berikut adalah penjelasan dari Gambar 7.

a. Keluar dari halaman panduan

b. Gambar penjelasan panduan instalasi dan penggunaan aplikasi

c. Teks informasi penjelasan panduan intalasi dan penggunaan aplikasi

d. Scroll untuk menampilkan panduan instalasi dan penggunaan aplikasi. Scroll dapat digeser secara horizontal

\subsection{Efektifitas Aplikasi pada Pengguna}

Pengujian dilakukan pada siswa kelas 4 Sekolah

Dasar Islam Diponegoro Kecamatan Dampit Kabupaten Malang dengan total 38 siswa. Pengujian dilakukan sebelum (pretest) dan sesudah (posttest) penggunaan aplikasi.

Dari hasil pengujian, SD Islam Diponegoro mengalami peningkatan nilai rata-rata pemahaman dari 60,81 menjadi 77,89 .

Pengujian juga dilakukan dengan memberikan kuesioner pada siswa. Hasil penilaian menggunakan kuesioner dapat dilihat pada Gambar 8.

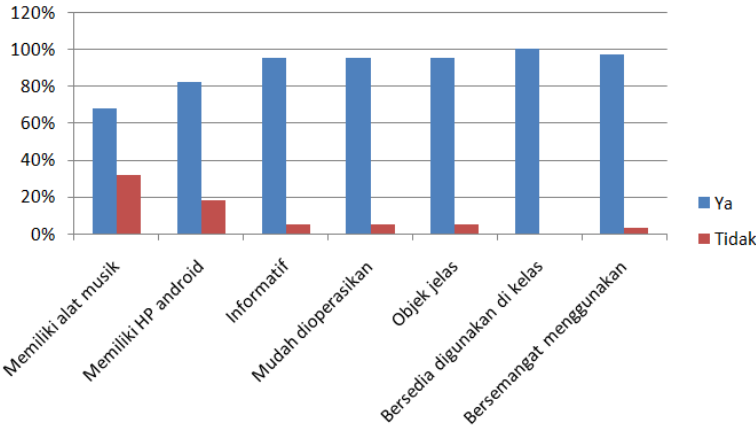

Gambar 8. Grafik Persentase Kuesioner Siswa SD Islam Diponegoro

Berdasarkan Gambar 8 pengujian dilakukan pada SD Islam Diponegoro dengan jumlah peserta 38 siswa. Sebesar $68 \%$ siswa memiliki alat musik dan sebanyak $82 \%$ siswa memiliki handphone android. Adapun terhadap informasi yang disajikan pada aplikasi, 95\% siswa menyimpulkan bahwa aplikasi AR alat musik modern sudah informatif. Implementasi teknologi augmented reality pada buku panduan $\mathrm{AR}$ alat musik modern masih tergolong baru, namun dalam penerapannya siswa merasa mudah mengoperasikan aplikasi dengan persentase sebesar 95\%. Serta 95\% siswa menilai objek 3D mudah dimengerti dan jelas. Adapun setelah pengujian, $100 \%$ siswa menilai bahwa aplikasi AR alat musik modern layak digunakan sebagai media pembelajaran di kelas.

Pengujian juga dilakukan dengan memberikan kuesioner pada tenaga pendidik, dalam hal ini adalah Guru di Sekolah Dasar Islam Diponegoro. Hasil penilaian menggunakan kuesioner dapat dilihat pada Gambar 9.

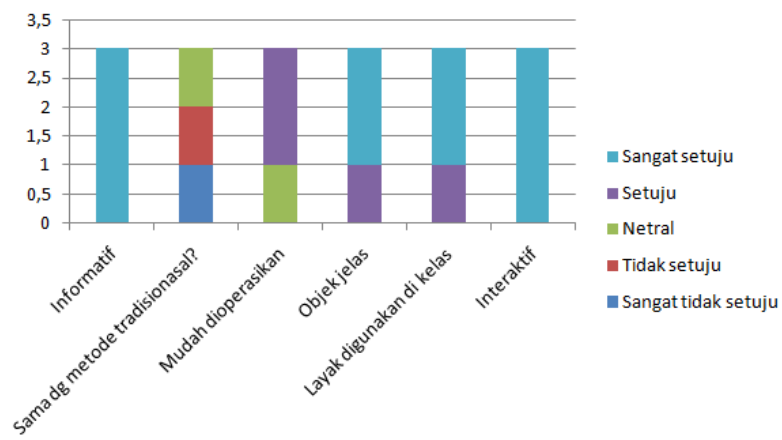

Gambar 9. Grafik Rekapitulasi Hasil Jawaban Kuesioner Guru

Berdasarkan hasil penilaian guru SD Islam Diponegoro sebanyak tiga guru menilai dengan skor 5 (sangat setuju) bahwa informasi yang disajikan aplikasi sudah interaktif. Adapun penilaian tersebut dilakukan terhadap pertanyaan "apakah secara keseluruhan, aplikasi ini memiliki efektifitas yang 
sama dengan metode tradisional baik berupa buku maupun video tutorial?", masing-masing dari ketiga guru menjawab dengan skor 1 (sangat tidak setuju), skor 2 (tidak setuju) dan skor 3 (netral). Adapun untuk guru yang menilai dengan skor 3 (netral) memberikan alasan bahwa kedua media (aplikasi $\mathrm{AR}$ alat musik modern dan media tradisional) memiliki kelebihan dan kekurangan masing-masing dimana guru tersebut memberikan keterangan bahwa penggunaan handphone dalam instensitas yang lama kurang baik bagi kesehatan mata anak-anak. Dua dari tiga guru juga menilai dengan skor 4 (setuju) bahwa aplikasi mudah digunakan, sedangkan sisanya memberikan skor 3 (netral) dengan alasan keterbatasan penglihatan melihat objek terang menyebabkan sulitnya pengoperasian. Setelah menggunakan aplikasi, dua dari tiga guru memberikan skor 5 (sangat setuju) dan satu guru memberikan skor 4 (setuju) terhadap objek 3D yang ditampilkan secara jelas dan menarik sehingga siswa akan senang dan tertarik untuk menggunakan media pembelajaran alat musik modern ini. Dua guru juga menilai bahwa aplikasi layak digunakan sebgai media pembelajaran dikelas dengan skor 5 (sangat setuju) serta sisanya memberikan skor 4 (setuju). Namun dari segi keinteraktian aplikasi, sebesar $100 \%$ dari ketiga guru memberikan tanggapan bahwa aplikasi sudah interaktif.

\section{KESIMPULAN}

Berdasarkan hasil penelitian Aplikasi Berbasis augmented reality pada Buku AR alat musik modern untuk anak didapatkan kesimpulan sebagai berikut:

a. Penggunaan aplikasi berbasis augmented reality pada buku pengenalan alat musik modern untuk anak terbukti dapat digunakan sebagai media pembelajaran yang terjangkau. Terbukti dengan hasil penilaian kuesioner siswa di SD Islam Diponegoro yang $82 \%$ dari siswa memiliki handphone android, serta dibuktikan bahwa dua dari tiga guru menilai dengan skor 5 (sangat setuju) dan sisanya menilai dengan skor 4 (setuju) bahwa aplikasi layak digunakan di kelas.

b. Aplikasi berbasis augmented reality pada buku pengenalan alat musik modern untuk anak dapat mengingkatkan tingkat pemahamansiswa siswa dalam belajar alat musik modern. Terbukti dengan hasil pengujian pretest dan postest pada siswa di SD Islam Diponegoro mengalami peningkatan nilai rata-rata pemahaman dari 60,81 menjadi 77,89 .

c. Penggunaan aplikasi berbasis augmented reality pada buku AR alat musik modern sebagai media pembelajaran dirasa cukup interaktif dalam menyajikan komunikasi aktif dua arah antara aplikasi dan pengguna. Terbukti dengan tanggapan ketiga responden guru dari SD Islam Diponegoro yang menilai bahwa aplikasi sudah interaktif dengan ratarata skor 5 (sangat setuju).

\section{PUSTAKA}

Azuma, R., Baillot, Y., Behringer R. 2001. Recent Advances in Augmented Reality: IEEE Computer Graphics and Applications.

Jalai, Fasli. 2012. Meningkatkan Kesadaran Masyarakat akan Pentingnya PAUD. Jakarta: Bulletin PADU.

Mustika, Rampengan, C. G., Sanjaya, R., \& Sofyan. 2015. Implementasi Augmented Reality Sebagai Media Pembelajaran Interaktif . Citec Journal, Vol. 2, No. 4.

Noviana, F., Akhriza, T.M., Farida, E., 2017, Implementasi Teknologi Augmented Reality Untuk Peningkatan Pemahaman Rambu-Rambu Lalu Lintas. Prosiding SENIATI 2017, Vol. 3. No. 1, ITN Malang.

Punuindoong, D.H.F, \& Meidia, H. 2017. Rancang Bangun Aplikasi Pembelajaran Chord dan Melodi Gitar Berbasis Augmented Reality. ULTIMA Computing, Vol. IX, No. 1.

Rasjid, M., Sengkey, R., \& Karouw, S. 2016. Rancang Bangun Aplikasi Alat Musik Kolintang menggunakan Augmented Reality berbasis Android. E-journal Teknik Informatika , Volume 7, No.1.

Setyawan, R. A., \& Dzikri, A. 2016. Analisis Penggunaan Metode Marker Tracking Pada Augmented Reality Alat Musik Tradisional Jawa Tengah. Jurnal SIMETRIS, Vol 7 No 1.

Suryanto, T., Utami, E., \& Al Fatta, H. 2014. Rancang Bangun Virtual Gamelan Mobile Menggunakan Augmented Reality. JURNAL DASI , Vol. 15 No. 1.

Villagomez,G. 2010. Augmented Reality. University of Kansas 